Т.О. КУЗЬМННА, Ю.В. БЕРЕЗОВСЬКИЙ, Л.О. СТРЕЛЮК

Херсонський начіональний технічний університет

\title{
УДОСКОНАЛЕННЯ СИСТЕМИ УПРАВЛІННЯ ЯКІСТЮ ПОСЛУГ ПІДПРИЕМСТВ
}

\author{
Т.О. КУЗЬМИНА, Ю.В. БЕРЕЗОВСКИЙ, Л.А. СТРЕЛЮК \\ Херсонский национальный технический университет \\ УСОВЕРШЕНСТВОВАНИЕ СИСТЕМЫ УПРАВЛЕНИЯ \\ КАЧЕСТВОМ УСЛУГ ПРЕДПРИЯТИЙ
}

\section{T. KUZMINA, Y. BEREZOVSKY, L. STRELIUK \\ Kherson national technical university \\ IMPROVEMENT OF THE SERVICE QUALITY MANAGEMENT SYSTEM FOR THE ENTERPRISES}

\section{https://doi.org/10.36910/6775-2310-5283-2019-12-31}

Мета. Аналіз та обтрунтування основних напрямів підвищення якості надання послуг $i$ розробка рекомендацій щэодо ефективного управління процесом обслуговування споживачів у спеціалізованому магазині «Дім Кави» (м. Херсон).

Методика. Загальною методологічною основою дослідження стали наукові напрачювання вітчизняних $i$ зарубіжних учених у сфері менеджменту якості. $У$ дослідженнях використано низку загальнонаукових $і$ спеціальних методів дослідження, які передбачені чинними міжнародними стандартами на системи управління якістю.

Результати. Проблема підвищення рівня якості торговельного обслуговування $\epsilon$ ваэжливим завданням, вирімення якого забезпечує економічний розвиток вітчизняних організачій, підприємств та забезпечення конкурентоспроможності й існування в умовах конкурентної боротьби. Дуже важливо підкреслити, щзо управління якістю послуг має багато рівнів, $i$, внаслідок иъього, існує необхідність розподілу функцій управління між різними учасниками иьього процесу і узгодження їхніх дій.

Дослідження проводили на прикладі спеціалізованого магазину «Дім Кави», м. Херсон. "Дім Кави» - ие мережа спеціалізованих магазинів з продажу кави, кавового обладнання $з$ дегустаційною залою. Проектування системи управління якістю обслуговування на торговельних підприємствах повинне будуватися з урахуванням умов діяльності підприємства та відповідно до рекомендацій стандартів ISO серії 9000.

Проведено теоретичні дослідження сучасного стану роботи підприємств з надання послуг, тенденщії розвитку ринку послуг. Встановлено, щуо якість обслуговування споживачів - визначальний фактор конкурентоспроможності торговельного підприємства. В роботі проведено аналіз стану виробничих прочесів управління якістю, досліджено елементи системи управління якістю послуг у спеціалізованому магазині «Дім Кави», м. Херсон та розроблено структурно-логічну схему взаємозв'язку елементів системи якості відповідно до вимог стандарту ISO 9001:2015. Розроблено рекомендації щздо підвищення ефективності функиіонування системи управління якістю послуг. 
Наукова новизна. Наукова новизна одержаних результатів полягає в розкритті ролі елементів системи управління якістю у підвищенні рівня обслуговування споживачів продукиї та послуг торговельного підприсмства.

Практична значимість За результатами досліджень було розроблено рекомендаціі щзодо підвищення ефективності функиіонування системи управління якістю послуг торговельного підприємства, які буде використано у магазині «Дім Кави», м. Херсон.

Ключові слова. Система управління якістю, послуга, показники якості, метод, персонал.

\section{Постановка проблеми у загальному вигляді і її зв'язок 3 важливими} науковими та практичними завданнями. Найважливішою складовою культури торгівлі $€$ торговельне обслуговування клієнтів, тобто діяльність торговельного працівника при безпосередній взаємодії з покупцем, яка спрямована на задоволення його потреб у процесі придбання товару та/або послуги. Якість обслуговування покупців у підприємстві торгівлі визначається великою кількістю елементів, взаємодія яких формує певну систему. Чим досконаліша система торговельного обслуговування, тим вищий рівень його якості у конкретному підприємстві торгівлі і тим більшою буде його конкурентна перевага. Саме необхідність цілеспрямовано впливати на підвищення конкурентоспроможності об'єкта торгівлі $\epsilon$ актуальним напрямком досліджень 3 питань оцінювання якості обслуговування.

Всі внутрішні фактори економічного, організаційно-технічного i технологічного характеру, що впливають на товарообіг підприємства торгівлі, визначають також і стан якості торговельного обслуговування, відображаючи умови торговельної діяльності і залежність від роботи відповідних служб апарату управління і керівництва. Від персоналу торговельного підприємства повністю залежить якість самого процесу обслуговування покупців на момент продажу товарів. Тут важливу роль відіграють професійна майстерність продавця, його особиста культура, витримка, такт, зацікавленість у результатах праці.

Аналіз останніх досліджень, у яких започатковано вирішення проблеми. Світові тенденції свідчать про те, що частка послуг у загальному обсязі ринку постійно зростає. Що стосується України, то вона суттєво відстає в розвитку цього сектору економіки. Відставання у сфері послуг значною мірою зумовлено тим, що на підприємствах сфери послуг фактично відсутні методики впровадження i застосування систем управління якістю послуг. Крім того, підприємства не усвідомлюють, що ринок товарів швидкими темпами переростає в ринок послуг. Тому тема роботи є достатньо актуальною і своєчасною. Відомі науковці, фахівці з менеджменту якості Дж. Джуран, Е. Демінг, Ф. Кросбі, К. Ісікава, 
А. Фейгенбаум та інші розробили принципові схеми загального управління якістю, які стали підгрунтям систем нормативів і стандартів якості ISO серії $9000[1,2]$. Також проблемам управління якістю послуг на підприємствах торгівлі присвячена низка досліджень таких вчених як А. Мазаракі, В. Апопій, В. Галюк, В. Геєць, В. Жигалов, І. Маркіна, Л. Лігоненко, М. Виноградський, Н. Ушакова, О. Фрідман, П. Саблук, С. Бабенко, С. Гелей, Ф. Хміль, Я. Гончарук [3, 4]. Але в науково-технічній літературі відсутня узагальнена точка зору щодо однозначності виділення базових критеріїв ефективності діяльності організацій і підприємств торгівлі, залишаються не висвітленими конкретні питання управління якістю торговельного обслуговування.

Цілі статті. Метою роботи є систематизоване узагальнення та обгрунтування основних напрямів підвищення якості надання послуг і розробка рекомендацій щодо забезпечення ефективного управління процесом обслуговування споживачів персоналом торговельного підприємства «Дім Кави», м. Херсон.

Об'єкт дослідження. Процеси формування системи управління якістю послуг торговельного підприємства.

Методи дослідження. Загальною методологічною основою дослідження стали наукові напрацювання вітчизняних і зарубіжних учених у сфері менеджменту якості. У дослідженнях використано низку загальнонаукових i спеціальних методів дослідження, які передбачені чинними міжнародними стандартами на системи управління якістю.

Виклад основного матеріалу дослідження з повним обгрунтуванням отриманих наукових результатів. Якість продукції та послуг організації визначають здатністю задовольняти замовників, а також передбаченим i непередбаченим впливом на відповідні зацікавлені сторони.

Система управління якістю обслуговування повинна розглядатися як удосконалення різноманітних якостей окремих суб'єктів. При цьому дуже важливо підкреслити, що управління якістю послуг має багато рівнів, i внаслідок цього, існує необхідність розподілу функцій управління між різними учасниками цього процесу і узгодження їхніх дій [5].

Якість послуг обумовлює проходження підприємством трьох ступенів. Перший - підбір персоналу та його навчання. Другий - стандартизація процесу надання послуг у закладі. Зазвичай компанія розробляє план надання послуг та процес їх надання, спрямований на виявлення вузьких місць. Третій - контроль ступеня задоволення клієнтів обслуговуванням за допомогою аналізу скарг та пропозицій, вивчення переваг клієнтів [6]. 
Більшість факторів, які за Ф. Котлером визначають якість послуги, можна безумовно віднести і до факторів, що визначають якість обслуговування: надійність - точне виконання замовлення; уважливість - можливість допомогти при виборі послуг; компетентність обслуговуючого персоналу; співчування та турбота персоналу, індивідуальний підхід до споживача послуг; матеріальність - можливість побачити меню, наявність інформаційних матеріалів [6].

Дослідження проводили на прикладі спеціалізованого магазину «Дім Кави», м. Херсон. «Дім Кави» - це мережа спеціалізованих магазинів 3 продажу кави, кавового обладнання з дегустаційною залою. На сьогоднішній день «Дім Кави» - це команда із співробітників, дилерів, клієнтів і постачальників. Це мережа магазинів СНД, які працюють 3 такими світовими брендами як: «Blaser», «Saeco», «Gaggia», «Elektra», «Schaerer», «Dalla corte», «Blaser star», «Spidem», «Delonghi», «Bravilor bonomat», «Macap», «Mazzer».

«Дім Кави» займається оптовими i роздрібними продажами. Це унікальний магазин: тут радо вітають кожного клієнта, розповідають про культуру споживання кави, надають можливість продегустувати вподобаний сорт кави, не відволікаючись на сторонні запахи, побачити в роботі кавове обладнання і тут же придбати вподобану модель, не тільки навчитися роботі на кавоварці, але й дізнатися всі тонкощі приготування якісних напоїв. Крім того можна придбати супутні кавові аксесуари і товари (сервізи, молочники, ложки, келихи для макіятто, витратні матеріали для вендінгових машин).

«Дім Кави» працює з швейцарським брендом кави Blasercafe. Blasercafe провідний світовий виробник кави. Blaser пропонує споживачеві великий асортимент кавових букетів на будь-який смак. Різноманіття кавових сумішей досягається шляхом змішування різних сортів кавових зерен, створюються неповторні купажі, здатні задовольнити найвишуканіші вимоги кавових гурманів.

Якість сировини компанії Blaser гарантується ії членством у найбільш значущих і авторитетних кавових організаціях: SCAE (Свропейська асоціація кави speciality); Міжнародна кавова організація (International Coffe Organization - ICO); «UTZ CERTIFIED Good Inside» - здійснює діяльність протягом всього циклу від плантації до обсмажувального виробництва; Організація з сертифікації кави speciality «CSC»- сприяє розвитку культури споживання якісної кави тощо.

Наявність системи управління якістю вимагає компетентності персоналу. Для гарантії того, що колектив «Дім Кави» володіє необхідною 
компетентністю, керівництво організації розробляє і підтримує «план розвитку персоналу» і пов'язані з цим процеси.

Удосконалення та розвиток нормативного забезпечення, що грунтуються на оптимальності та узгодженості, мають вирішальне значення для підвищення ефективності його застосування. Тому необхідно вносити зміни та доповнення, що відповідають сучасним потребам, базуються на світових тенденціях, досвіді економічно розвинених країн.

Таким чином, удосконалення чинної нормативної бази, розроблення нових стандартів, приведення їх у відповідність до нових суспільних запитів, гармонізація 3 міжнародними та європейськими нормами $є$ актуальними завданнями, що мають важливе соціально-економічне значення для ефективного обслуговування споживачів. Проектування системи управління якістю обслуговування на торговельних підприємствах повинне розбудовуватися з урахуванням умов існування підприємства та відповідно до рекомендацій стандартів ISO серії 9000.

Відповідно до вимог стандарту ДСТУ ISO 9001:2015 компетентність персоналу може бути визначена за допомогою наступних дій:

- визначення професійних і особистих компетенцій, які могли б бути необхідні організації в короткостроковій і довгостроковій перспективі, відповідно до місії, бачення стратегії, політики й цілей організації;

- визначення поточного рівня компетентності в організації та невідповідності між тим, що $\epsilon$, і тим, що необхідно і могло б знадобитися в майбутньому;

- виконання дій, спрямованих на поліпшення або отримання необхідної компетентності з тим, щоб усунути невідповідність;

- аналіз та оцінювання результативності виконаних дій 3 тим, щоб гарантувати, що необхідна компетентність забезпечена;

- підтримка досягнутого рівня компетентності [5].

3 метою підсилення контролю роботи персоналу зі споживачами та як інструмент поліпшення якості сервісу, керівництвом магазину «Дім Кави» впроваджено дослідницький метод з якості обслуговування Mystery Shopping (таємничий покупець (ТП). Mystery Shopping - метод дослідження, який застосовується як у рамках маркетингового дослідження, направленого на оцінювання споживчого досвіду, отриманого клієнтом у процесі придбання товару або послуги, так i 3 метою вирішення організаційних завдань, наприклад, визначення рівня дотримання стандартів обслуговування кліснтів 
співробітниками в організації та ін. Mystery Shopping використовується у формі довгострокових чи постійних програм контролю сервісу і мотивації персоналу. Модифікації програми включають використання аудіо i відеозапису процесу обслуговування.

Критерії, за якими оцінюється робота персоналу магазину «Дім Кави», 3 точки зору обслуговування, надаються безпосередньо організацією Mystery Shopping, але менеджер магазину має право доповнити або змінити цей список.

Перед початком користування послугами таємничого покупця керівництво магазину збиратє всезагальні збори персоналу задля оповіщення про перевірки і принцип роботи таємничого покупця. Також вважається необхідним сповістити персонал не просто про початок Mystery Shopping, а й про впровадження системи мотивації.

У роботі досліджено також наявні інструменти управління якістю послуг у спеціалізованому магазині «Дім Кави». Наприклад, моніторинг стану магазину, який забезпечує:

- збір та аналіз внутрішньої та зовнішньої інформації про стан підприємства;

- виявлення «вузьких місць» на підприємстві;

- аналіз та оцінку фінансових та інвестиційних операцій;

- аналіз зовнішнього середовища та оцінку нових можливостей;

- контроль ризиків діяльності;

- виявлення резервів зниження собівартості, підвищення прибутку підприємства;

- виявлення кризових явищ у фінансовій та господарській діяльності.

Метою моніторингу підприємства $є$ визначення взаємозалежності між різними показниками, які характеризують фінансово-господарську діяльність.

Головне в моніторингу - оцінка динаміки основних показників, місце підприємства серед конкурентів. Ось чому треба аналізувати економічні показники в часі (за місяць, квартал, півріччя, рік, декілька років).

Для аналізу та оцінювання показників якості послуг в магазині «Дім Кави» застосовують методи, які умовно можна розділити на дві групи:

I. Залежно від способу отримання інформації: об'єктивний, диференційований та комплексний методи.

II. Залежно від джерела інформації: експертний, соціологічний (базується на визначенні якості послуг на основі вивчення думки споживачів про неї).

Стратегія високої якості та безпеки послуг у спеціалізованому магазині «Дім Кави» передбачає постійну і особисту участь керівництва у виробничих 
питаннях. 3 цією метою розробляється та впроваджується стандарт обслуговування, який підтвердить і забезпечить заявлений рівень якості та безпеки послуг, що надає магазин, з метою захисту інтересів споживачів.

Основою проектування системи управління якістю обслуговування $\epsilon$ структуризація цілей управління окремими працівниками 3 урахуванням специфіки їх видів робіт та специфіки роботи самого торговельного закладу. Для побудови системи управління якістю послуг у спеціалізованому магазині «Дім Кави» ми пропонуємо структурно-логічну схему, що грунтується на змістовному аспекті управління якістю обслуговування (рис. 1). На схемі показано взаємозв'язок елементів системи якості відповідно до вимог стандарту ISO 9001:2015, які вже впроваджено в спеціалізованому магазині «Дім Кави», а напівжирним шрифтом та жирними лініями виділено ті елементи, що пропонуються до впровадження або вимагають удосконалення для підвищення результативності дії системи.

Аналіз схеми, представленої на рисунку 1, дозволив встановити необхідні складові удосконалення системи управління якістю надання послуг. Удосконаленню процесу надання послуг споживачам може допомогти впровадження системи стандартів обслуговування.

Ця система включає в себе:

1. Стандартизацію роботи персоналу - детальний опис того, що, як і в яких ситуаціях повинен робити персонал.

2. Навчання кадрів. Персонал повинен знати продукцію магазину та правила роботи з клієнтом; тренінги і семінари такої спрямованості необхідно проводити систематично. Наприклад, тренінги від компаній-виробників обладнання, 3 яким працює магазин, та розширити майстер класи від професійних бариста також для збільшення об'єму продаж техніки можна організувати тренінги 3 «Техніки ефективних продаж» тощо.

3. Контроль. В магазині використовують метод Mystery Shopping, але таємничий покупець може перевірити тільки якість обслуговування, а потрібно перевіряти ще й якість приготування кави, тому треба також залучити таємничого покупця - кавового сомільє. Результати контролю можуть бути успішно інтегровані в систему мотивації співробітників.

4. Розробити та впровадити чітку систему мотивації з використанням інструментів матеріальної та нематеріальної зацікавленості співробітників. Наприклад, ефективні номінації за кращі результати: кращий продавець, кращий бариста, самий доброзичливий персонал і т. ін. 
Товарознавчий вісник. - 2019. - Випуск 12.

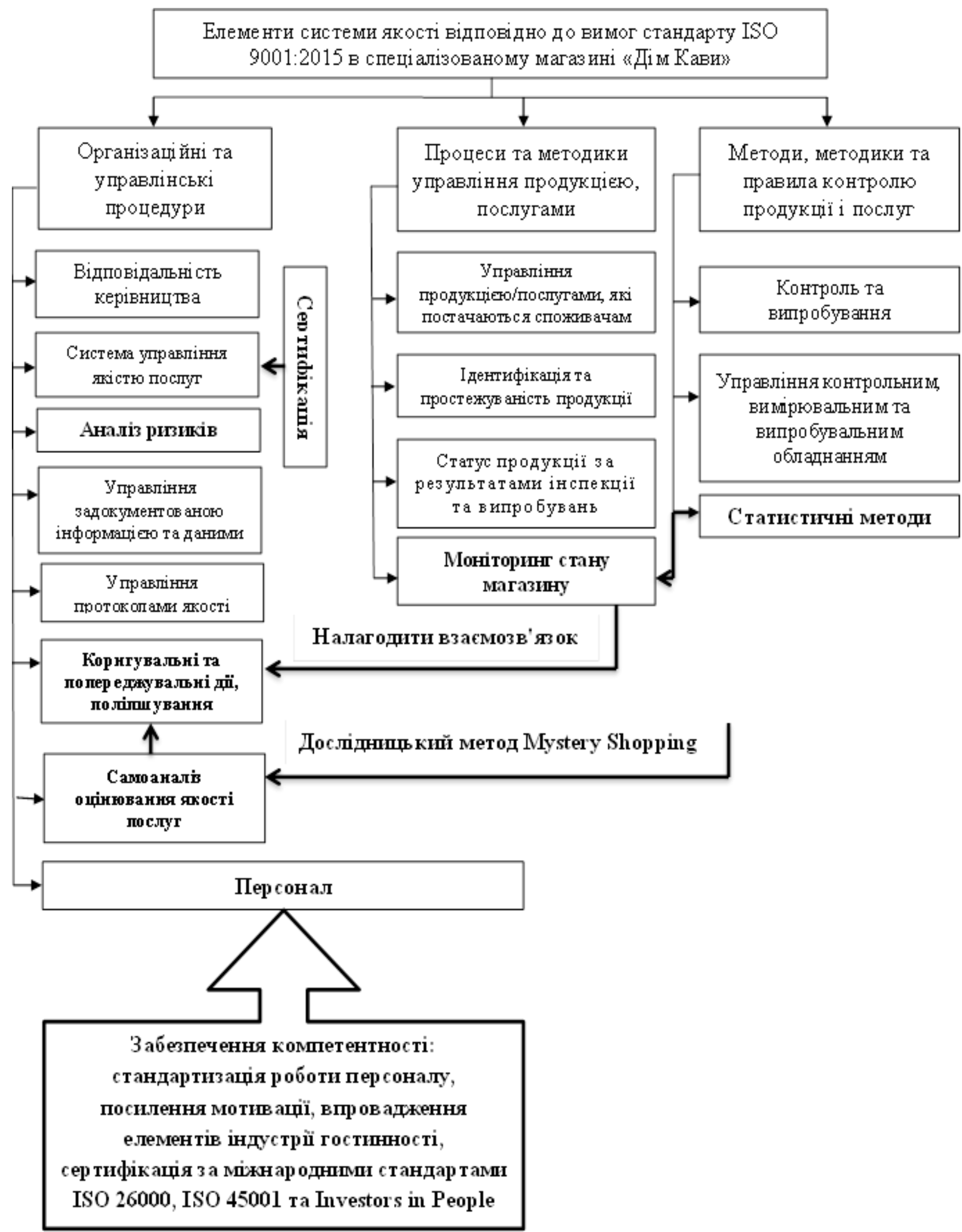

Рис. 1. Структурно-логічна схема елементів системи управління якістю послуг у спеціалізованому магазині «Дім Кави», м. Херсон 
Всі призи, заохочення, події, пов'язані з роботою компанії над якістю обслуговування, повинні висвітлюватися на зборах, у листах, сайті компанії i, по можливості, у зовнішніх ЗМІ.

5. Здійснювати сертифікацію послуг на відповідність вимогам безпеки життя i здоров'я споживачів, охорони навколишнього середовища, встановленим в законодавчих актах, державних стандартах, санітарних правилах і нормах, будівельних нормах і правилах, правилах виробництва та реалізації продукції та послуг підприємства.

6. Звернути увагу на «секретний елемент» обслуговування - гостинність як фактор удосконалення організації обслуговування споживачів. Магазин повинен бути більше, ніж супермаркет з приготування кави. Це святилище фізичного і щиросердечного спокою, відпочинку за чашкою еспресо або капучино. Сюди потрібно включити фізичну атмосферу, чистоту, відчуття компетентності і турботи з боку обслуговуючого персоналу.

7. Адміністрації магазину «Дім Кави» необхідно попрацювати із меню закладу. Не всіх споживачів влаштовує асортимент напоїв. Можна запропонувати провести спеціальне анкетування серед гостей закладу, у якому необхідно відповісти на питання, які напої вони хотіли б бачити в меню, можливо ввести в меню чай, рослинне молоко тощо.

\section{Висновки та перспективи подальших досліджень.}

1. Проведено теоретичні дослідження сучасного стану роботи підприємств з надання послуг, тенденції розвитку ринку послуг.

2. Встановлено, що якість обслуговування споживачів - визначальний фактор конкурентоспроможності торговельного підприємства. Надання широкого спектру послуг поряд із високою їх якістю може забезпечити ефективну діяльність підприємства.

3. У роботі проведено аналіз стану виробничих процесів управління якістю, досліджено елементи системи управління якістю послуг у спеціалізованому магазині 3 продажу кави та кавового обладнання «Дім Кави», м. Херсон та розроблено структурно-логічну схему взаємозв'язку елементів системи якості відповідно до вимог стандарту ISO 9001:2015.

4. Розроблено рекомендації, щодо підвищення ефективності функціонування системи управління якістю послуг у магазині «Дім Кави».

5. У подальшій роботі планується розглянути можливість впровадження у магазині «Дім Кави» положень міжнародних стандартів 3 соціальної відповідальності ISO 26000, з безпеки праці та охорони здоров'я ISO 45001 та стандарту Investors in People. 


\section{Список використаних джерел}

1. Шаповал M.I. Менеджмент якості: підручник. - К.: Знання, 2006. - 471 с.

2. Системи управління якістю: навч. посіб. для студентів вищих навчальних закладів / Т.О. Кузьміна, В.В. Свтушенко. - Херсон: Олді-Плюс, 2018. - 500 с.

3. Світовий ринок товарів та послуг: підруч. для студ. вищ. навч. закл. / за загальн. ред. А.А. Мазаракі, Т.М. Мельник. - К.: Київ. нац. торг.-екон. ун-т, 2015. - 720 с.

4. Теорія та практика торговельного обслуговування: навч. посібник / В.В. Апопій, І.П. Міщук, С.І. Рудницький, Ю.М. Хом’як / За ред. В.В. Апопія. - К.: Центр навчальної літератури, 2005. - 459 с.

5. Система управління якістю. Вимоги. ДСТУ ISO 9001:2015 (ISO 9001:2015, IDT). - [Чинний від 2016-01-07] - К.: ДП УкрНДНЦ, 2016. - 18 с. (Національний стандарт України).

6. Котлер, Ф. Маркетинг - менеджмент. Анализ, планирование, внедрение, контроль / Ф. Котлер; пер. с англ.; под ред. О.А. Третьяк, Л.А. Волковой, Ю.Н. Каптуревского. - СПб.: Питер, 1999. - 896 с.

Цель. Анализ и обоснование основных направлений повымения качества предоставления услуг и разработка рекомендаций по эффективному управлению прочессом обслуживания потребителей в специализированном магазине «Дом Кофе» (2. Херсон).

Методика. Общей методологической основой исследований стали научные наработки отечественных и зарубежных ученых в области менеджмента качества. В исследованиях использован ряд общенаучных и специальных методов, которые предусмотрень действуюшими международными стандартами на системы менеджмента качества.

Результаты. Проблема повышения уровня качества торгового обслужсивания является важной задачей, решение которой обеспечивает экономическое развитие отечественных организаций, предприятий для обеспечения конкурентоспособности и существования в условиях конкурентной борьбы. Очень важно подчеркнуть, что управление качеством услуг имеет много уровней, и, вследствие этого, существует необходимость распределения функиий управления между различными участниками этого проиесса и согласования их действий.

Исследования проводились на примере специализированного магазина "Дом Кофе», 2. Херсон. "Дом Кофе» - это сеть специализированных магазинов по продаже кофе, кофейного оборудования с дегустационным залом. Проектирование системы управления качеством обслуживания на торговых предприятиях должно строиться с учетом условий деятельности предприятия и в соответствии с рекомендащиями стандартов ISO серии 9000.Проведены теоретические исследования современного состояния работь предприятий по предоставлению услуг, тенденции развития рынка услуг. Установлено, что качество обслуживания потребителей - определяющий фактор конкурентоспособности предприятия. В работе проведен анализ производственных процессов управления качеством, исследованы элементы системы управления качеством услуг в спечиализированном магазине "Дом Кофе», г. Херсон и разработана структурнологическая схема взаимосвязи элементов системы качества в соответствии с требованиями стандарта ISO 9001:2015.

Разработаны рекомендаџии для повышения эффективности функиционирования системы управления качеством услуг в магазине «Дом Кофе». 
Научная новизна. Научная новизна исследования заключается в раскрытии роли элементов системы управления качеством в повышении уровня обслужсивания потребителей продукиии и услуг предприятия.

Практическая значимость. По результатам исследований были разработаньл рекомендации для повышения эффективности функциионирования системы управления качеством услуг торгового предприятия, которые будут использованы в магазине "Дом Кофе» г. Херсон.

Ключевые слова. Система управления качеством, услуга, показатели качества, метод, персонал.

Purpose. Analysis and substantiation of the main directions of improving service provision quality and development of recommendations for effective management of customer service in the specialized store «Dim Kavy» (Kherson).

Methodology. The general methodological basis of the research was achievements of domestic and foreign scientists of quality management. The studies used methods based on the international standards of the quality management system.

Findings. The quality of service directly affects the efficiency of the enterprise. The high level of service quality provides growth of profitability and competitiveness of domestic enterprises in the conditions of a market economy.

It should be noted that the quality management system has many levels. Employees of each level must perform their functions in this system and coordinate their actions with employees of other levels.The research was conducted on the example of a specialized store "Dim Kavy", Kherson. "Dim Kavy» is a network of specialized shops selling coffee, coffee equipment with a tasting room. When designing a quality management system for retail enterprises it is necessary to take into account the working conditions of the enterprise. It is also necessary to follow the recommendations of the standards of ISO series 9000. The theoretical researches of the current state of work of enterprises on providing services, tendencies of the market of services development are carried out. It has been established that the quality of customer service is the determining factor of the success and competitiveness of a trading company. The work analyzes the state of production processes in quality management, explains the elements of the quality management system at the specialized store «Dim Kavy», Kherson, and elaborates the structural and logical scheme of interconnection of the elements of the quality system in accordance with the requirements of the standard ISO 9001:2015.

Recommendations for improving the efficiency of the quality management system in the store «Dim Kavy» have been developed.

Originality. The scientific novelty of the obtained results is to determine the role of elements of the quality management system in increasing the level of service of consumers of products and services of the trade enterprise.

The practical value. According to the results of the research, recommendations have been developed to improve the efficiency of the quality management system of the trading enterprise, which will be used at the store "Dim Kavy» in Kherson.

Keywords. Quality management system, service, quality indicators, method, personnel.

Рекомендовано до публікації доктором технічних наук, професором Херсонського НТУ Валько М.I. Дата надходження до редакиії 6.02.2019 